\title{
The role of e-learning service quality and e-trust on e-loyalty
}

\author{
Chuong Hong Pham ${ }^{a}$, Ngan Hoang Vu ${ }^{a^{*}}$ and Giang Thi Huong Trana
}

\begin{tabular}{l}
${ }^{a}$ National Economics University, \\
\hline C H R O N I C L E \\
\hline Article history: \\
Received: January 20, 2020 \\
Received in revised format: \\
March 252020 \\
Accepted: April 26, 2020 \\
Available online: \\
April 28, 2020 \\
\hline Keywords: \\
E-learning service quality \\
E-trust \\
E-loyalty
\end{tabular}

\section{A B S T R A C T}

\begin{abstract}
This study was conducted to explore the relationship between e-learning service quality, e-trust, and e-loyalty in Vietnam, an emerging country. Data collected from 666 students were analyzed by exploratory factor analysis, confirmation factor analysis and linear model using SPSS 20.0 and AMOS 20.0 software. The results indicate that e-trust and e-learning service quality had positive impacts on e-loyalty. The study also shows e-learning service quality and e-learners' privacy and security affect e-trust positively. Besides, there is a positive and significance relationship among elearners' privacy and security, e-learning support service quality, online course material quality and e-learning service quality. However, it is not yet possible to prove the role of online instructor quality in e-learning service quality.
\end{abstract}

\section{Introduction}

E-learning is the use of Internet and computers to create learning experiences (Horton, 2006). More specifically, Urdan and Weggen (2000) argue that e-learning could be seen as distributing course content via electronic means, such as Internet, Intranet, Extranet, satellite television, audio/ video tape, Interactive television and CD-ROM. Along with the strong development of information technology, e-learning has become an indispensable trend of the era (Sun et al., 2008). It satisfies the academic requirements in modern society and creates a continuous learning demand from businesses and universities (Wu et al., 2010). One of the great advantages of e-learning is that it frees interaction from the time and space constraints between learners and teachers or among learners (Trentin, 1997). In fact, hundreds of top universities all over the world have stepped up their e-learning system (Beqiri et al., 2009; Wu, 2016). For an emerging country as Vietnam, it is not exception. Most of the universities in Vietnam are trying to integrate into higher education system, including e-learning based the development of Internet infrastructure. Because of having lots of advantages and benefits, e-learning is a topic attracted many scholars around the world: Chiu et al. (2005) studied about e-learning's usability, quality, value and the decision to continue e-learning; Paechter et al. (2010) researched about student expectations and online learning experience, as well as their relationship to academic achievement and course satisfaction; Elango et al. (2008) studied online learning quality through analyzing e-learners' perceptions. However, most of the studies are explored in developed countries, with high science and technology qualifications, so the access to technology of students is more popular than it in developing countries like Vietnam (Pham et al., 2019). In the studies of information systems in Vietnam, some mentioned the assessment of online course quality and loyalty (Pham et al., 2019; Hue et al., 2019). However, trust has hardly appeared in e-learning studies in Vietnam. Meanwhile, when it comes to loyalty, Reichheld and Schefter (2000) argue that in order to gain customer loyalty, they must first earn their trust. Moreover, trust is a key to success in an online environment (Corritore et al., 2003), which is the foundation for loyalty, including the intention and willingness to buy from an online provider (Cyr, 2008). This study was conducted to explore how e-learning service quality and e-learning trust (e-trust) affect e-learning loyalty. 


\section{Literature review}

\subsection{E-learning loyalty (E-loyalty)}

Customer loyalty is the act of brand choice, and repeat purchase (Schultz \& Bailey, 2000) or it is the long-term commitment to re-buy a preferred product or service consistently from the same company (Parasuraman \& Grewal, 2000). Customer loyalty is critical to achieve a company's long-term profit (Jun \& Cai, 2001). Loyal customers are the best for the company because: These customers spend less on customer service and customer care; These customers will spend more on the company's products and services; These customers can potentially be free advertisers and ambassadors for the company through their words and recommendations (Parasuraman \& Grewal, 2000). In college, education is considered a service, and students are customers of e-learning service, so, e-learning student loyalty will be considered as customer loyalty in using e-learning services. According to Helgesen and Nesset (2007), student loyalty is crucial to higher-educational institutions. It is closely related to these two factors: students' satisfaction and school quality. Here the student acts as a customer and the school is the business that provides the service.

\subsection{The impact of e-trust on e-loyalty}

Trust is a psychological state that is willing to accept damage based on expectations of another person's intention or behavior (Rousseau et al., 1998). According to the scope, trust is understood as the relationship between two objects built on the belief of the partner's ability (Gambetta, 1998). However, Luhmann (1979) believes that trust is the starting point for the right behavior or the result of an action. Accordingly, the author argues that trust reduces the assumption in worst-case scenario that can occur in conditions of uncertainty effectively. Trust, on the other hand, is a decision made based on familiarity, expectation, and risk. Trust can exist on an individual level (Rotter, 1967) or at the enterprise level (Moorman et al., 1993). At the individual level, trust is an important factor in deciding when to choose someone to interact with (McKnight et al., 1998; Zaheer et al., 1998). At the enterprise level, trust is the foundation for businesses to consider and develop potential business relationships (Doney \& Cannon, 1997). Therefore, in many studies, trust has been interpreted as a central attribute in initiating, forming and maintaining relationships (Verhoef et al., 2002). The impact of trust on loyalty has been mentioned and confirmed in numerous studies (Lau \& Lee, 1999; Reichheld \& Schefter, 2000; Ribbink et al., 2004). Specifically, Lau and Lee (1999), examed the link between trust in a brand and loyalty to that brand and found a significant positive connection. In particular, many signs show that trust plays a more important role in the online environment than in the normal offline context (Harris \& Goode, 2004). Explaining this, Reichheld and Schefter (2000) argue, to gain customer loyalty one must first builds a trust. Since trust is seen as the key to success in an online environment (Corritore et al., 2003), it is the foundation of loyalty, including the intention to buy and the willingness to buy from a supplier online (Cyr, 2008). Therefore, we have come to the following hypothesis:

\section{Hypothesis 1: E-trust has a positive impact on e-loyalty.}

\subsection{The impact of e-learning service on e-loyalty}

E-learning service is understood as the responsiveness of service including overall durability, reliability, accuracy, easy operation, easy repair and other valuable attributes to perform its function (Kotler \& Armstrong, 2010). In addition, Gronroos (1984) stated that e-e-learning service is assessed by three main criteria: technical quality (Describing what services are provided and what customers receive from services.); functional quality (describing how the service is provided or how the customer will receive the results of that service) and image quality (describing the service shown through communication, and advertising alike). With the e-learning service applied with modern technology, it is understood as the overall support of the online provider through the Internet. Parasuraman et al. (1988) conceptualize e-learning service as a relative perception of the distance between customer expectations and the assessment of experience and e-learning service using a multi-item scale called the SERVQUAL model. The SERVQUAL model typically consists of five fundamental elements: tangibility (facilities and personnel appearance), reliability (the ability to deliver promised services reliably and accurately), responsiveness (ready to assist customers and provide timely services), service capacity (knowledge base of employees that create customer trust and confidence) and empathy (attention and personal care for customers by the service provider). Through studying the various scales, the authors found the measuring system of Pham et al. (2019) was sufficiently developed based on SERVQUAL and is suitable with the active research topic as well as the current status of using E-learning services of Vietnamese students. According to Zeithaml et al. (1996), the higher-level existence between the general quality of service and the retentions of customers has an effect on consumers' attitude. On top of that, according to the group of authors, behavioral intent can be captured through acquisition purpose, word, loyalty, grievance behavior and price sensitivity. Excellent quality of service frequently leads to the desire for favorite behavior, while low service quality tends to result in unfavorite intentions. Wolfinbarger and Gilly (2002) said that service quality is the second most important predicate of loyalty and the intention to repeat purchase. In a similar fashion, Pham, Williamson, and Berry (2018) also achieved a practical impact between the general quality of service and loyalty, and the results of the study further pointed out the existence of this relationship. Therefore, we offer the following theories: 
Hypothesis 2: E-learning service quality has a positive impact on e-loyalty.

\subsection{The impact of e-learning service quality on e-trust}

Recent evidence suggests service quality affects trust effectively (Sharma \& Patterson, 1999). In Web services, the role of trust is also increasingly significant. McKnight et al. (1998) asserted that the quality of the website will positively affect user trust. Especially in an increasingly competitive online environment, they can undoubtedly change service providers, so to improve this situation, organizations need to keep the overall service quality stable to make trust customers (Eisingerich \& Bell, 2008). Similarly, Akter et al. (2013) suggested that service quality has a practical influence on trust in the online environment. Through the above analysis, the authors found it is possible to believe the quality of service positively affects the trust of students, but very few studies in Vietnam confirm this, especially in an E-learning environment. This efficiently is a new point of the research topic. Therefore, we can move on to the following hypothesis:

Hypothesis 3: E-learning service quality has a positive impact on e-trust.

\subsection{The impact of e-learners' privacy and security on e-trust}

In an online environment, security can be better defined when it is considered with the concept of privacy (Wolfinbarger \& Gilly, 2002). Privacy is understood to be the absence of illegal access, collection and use of data about private life or matters of an individual (Jerman-Blažič \& Klobučar, 2005). More specifically, in the online environment, privacy related to control copying, collecting, spreading illegal information or any kind of misuse of information. Privacy is also defined by Anwar \& Fang (2006) as the protection and management of identity information. Kolsaker \& Payne (2002) assert that security reflects a perception of the reliability of the payment medium used in data transmission and storage mechanisms. Therefore, they provide an influential factor on the technical aspects: integrity, confidentiality, authentication and non-repudiation. The integrity of an information system refers to the inability to store or modifies data provided by third parties without permission. Confidentiality regarding data is viewed by authorized individuals. Authentication allows a certain activity to be performed only after identification or the identity of the other party is guaranteed during the transaction. Finally, do not give up referring to procedures that prevent individuals or organizations from denying they have performed an activity. Along with that, they additionally provide a scale for the security of online users: the reliability of the transactions being transmitted; the confidentiality of customer data is assured; confirmation immediately after the purchase has been made satisfactorily; clear information on how to purchase; security factors are combined, and customers are aware of these. Bart et al. (2005) point out security and privacy as a factor undoubtedly affecting customer trust in online retail. They believe online payment channels are not always safe and likely to be interrupted (Jones \& Vijayasarathy, 1998). This typically reduces customers' trustworthiness, disheartens them from providing personal information and making online purchases. In a similar fashion, Arnott et al. (2007) identify the site's security and privacy features along with shared values as important prerequisites of trust. At the same time, research by $\mathrm{Ha}$ (2004) and Arnott et al. (2007) also indicate a website has a higher level of trust when it protects user privacy. Therefore, we respectfully give the following hypothesis:

Hypothesis 4: E-learners' privacy and security have a positive impact on e-trust.

\subsection{The impact of e-learner's privacy and security on e-learning service quality}

The development of new technology, the increasing ability to process information and its complexity have made privacy an increasingly important issue. These give rise to consumer distrust about how their data are collected and processed. The magnitude of this problem is expressed by Udo (2001), who points out that the protection of privacy remains the greatest concern of internet users. In general, the lack of transparency in security and privacy in the online environment makes online users less confident to provide personal information, which is one of the primary obstacles to E-commercial development. Therefore, this aspect is essential when evaluating online service quality and popular in most online service quality research (Liu \& Arnett, 2000; Yoo \& Donthu, 2001; Wolfinbarger \& Gilly, 2003; Long \& McMellon, 2004). Therefore, we can continue with the following hypothesis:

Hypothesis 5: E-learner's privacy and security have a positive impact on e-learning service quality.

\subsection{The impact of e-learning support service quality and on e-service quality}

In the context of e-learning, the quality of support services is assessed through the aid provided by trainers and technicians, but usually more focused on online support technician (Cho \& et al., 2009; Lee, 2010). In addition, Masoumi and Lindström (2012) assert that technical assistance for learners remains an integral part of the success of E-learning programs. Therefore, appropriate help or training of them should be focused to help students easily master the e-learning environment (Marshall, 2006). As such, it is understandable that the quality of e-learning support services is the degree to which learners feel and fulfil the expectations of personal support services from the online learning system and often focus on technical support services are provided by the technician. For an online learning environment, students learn by interacting with instructions programmed on the system, so all the problems that learners may encounter must be anticipated to introduce first. Features 
intended for effective assistance. Especially eliminating the standard assumption that learners will know how and what to do (Masoumi \& Lindström, 2012). Also, technical support, announcements, instructions, and account management support are required more than lecture related issues (Masoumi \& Lindström, 2012). Therefore, the effectiveness of academic support services can affect the fundamental quality of online learning services from learners' perceptions (Laurillard, 2013). Therefore, we give the following hypothesis:

Hypothesis 6: E-learning support service quality has a positive impact on e-learning service quality.

\subsection{The impact of online instructor quality on e-learning service quality}

It can be seen that e-learning has changed the role and responsibilities of lecturers. If traditional education is teacher-centered, education-centric environment, then online education is learner-centered. As a result, the role of lecturers also changes, and teachers become more instructors than teachers (Yang \& Cornelious, 2005). Specifically, the role of E-lecturers is to select and filter information for students to consider, ask thought-provoking questions and facilitate lively discussions (KettnerPolley, 1999). A lot of previous research indicates the quality of teachers is one of the key factors decided for a system of effective learning (Khan, 2005; Liaw et al., 2007; Selim, 2007). Liaw et al. (2007) claim that "instructors" are a vital aspect of E-learning. In an online environment, instructors need enough time to interact with students in their learning process (Khan, 2005). Facilitator guidance plays an important role in affecting learners' attitudes toward the E-learning system (Liaw et al., 2007). Therefore, the quality of lecturers should be considered when evaluating an E-learning system. Also, Henrie et al. (2015) assert the standard of online instructors is mainly based on the quality of lecturers. They sign up for online courses hoping for a professor who possesses extensive knowledge in the field of teaching, well-prepared in lectures, and has a great care for students' interest. Besides, they also want an online course with a strong interaction between faculty and students for better online learning results (Henrie et al., 2015). Therefore, we give the following hypothesis:

Hypothesis 7: Online instructor quality has a positive impact on e-learning service quality.

\subsection{The impact of online course material quality on e-learning service quality}

The quality of online course materials depends on how well-designed and managed learning environments are. Learners get many values from the course material with well-written, well-laid out, scientific, interactive, appropriate, useful, flexible and coverage (Shee \& Wang, 2008). Furthermore, Hay et al. (2008) stated that meaningful documents are documents in which the knowledge needed to learn must be suitable with other understanding and must contain core concepts and proposals. A recent trend in higher education is to create and provide online access to learning materials. Over the past two decades, scholars and higher education institutes have diversified teaching through Internet as a learning management system, videos that add knowledge to online classroom among countless Other developing educational technologies (Lee, 2006). Compared to traditional learning methods, the abundant and updated learning materials provided by the E-learning system can make learners feel that E-learning remain an effective form of learning (Lee, 2006; Lee et al., 2009).

Hypothesis 8: Online instructor quality has a positive impact on e-learning service quality.

\section{Methodology}

\subsection{Instrument}

The authors developed a questionnaire of 46 indicators to measure e-loyalty, e-trust, e-learning service quality, e-learner's privacy and security, e-learning support service quality, online instructor quality, online course material quality in Vietnam. Specifically, indicators related to e-loyalty, e-learning service quality, e-learning support service quality, online instructor quality, and online course material quality were adjusted by Pham et al. (2018) and Pham et al. (2019); Indicators related to e-trust were adjusted from Kassim and Asiah Abdullah (2010); The indicators related to e-learner's privacy and security were adjusted from DeLone and McLean (2003), Jun and Cai (2001), Parasuraman et al. (2005), Pham et al. (2019).

\subsection{Sampling}

We collected data from eight universities in Vietnam based on the criteria of the richness and diversity of the sector and the size of the training. All respondents have attended at least one E-learning course. The authors investigate the survey through an online questionnaire form. After collecting questionnaires, we filtered data by eliminating invalid votes, missing or unreliable information. The total number of participants collected was 696, after eliminating the inappropriate participants, the sample used for analysis was 666 participants (reaching 95.69\%).

\subsection{Method}

SPSS 20.0 and AMOS 20.0 statistical software were used to enter data and perform statistical analysis. Descriptive statistics are used to test variables of interest, including demographic variables. Analyzing Cronbach's Alpha coefficients to assess the reliability of the scales and compare the correlation coefficients of the total variable to eliminate unsuitable observed variables. Exploratory factor analysis (EFA) was used to test the scale value, determine the correlation between variables in the data set. We used confirmation factor analysis (CFA) to make sure the model of the constituent elements through the data sheet of EFA analysis previously, and the linear model structure (SEM) to test the research hypotheses. 


\section{Data Analysis}

\subsection{Respondent Profiles}

Table 1 shows the demographic characteristics of the sample. Of the 666 observations, males accounted for $42.0 \%$ (280 students), females accounted for $58.0 \%$ corresponding to 386 students. Junior accounted for $32.3 \%$ (215 students), freshman accounted for 29.9\% (199 students), sophomore accounted for 26.1\% (174 students), senior accounted for $10.1 \%$ (67 students) and five-year students accounted for $1.6 \%$ corresponding to 11 students. Non-working students make up 56.7\% (378 students), part-time working students account for 39.5\% (263 students) and 3.8\% of full-time working students corresponding to 25 students. Of the 666 observations, tuition fees paid by families accounted for 53.8\% (358 students), self-paying students accounted for $30.9 \%$ (206 students), students paid part of the fee accounts for $9.5 \%$ (63 students) and 29 students are paid by other institutions, equivalent to $4.4 \%$. Students studying online under 5 hours/ week accounted for the majority with $58.1 \%$ (387 students), from 5 to less than 10 hours/ week accounted for $32.3 \%$, only $8.6 \%$ of students spent over 10 hours / week for online learning. The number of students who have taken from 1 to 3 online courses accounts for the largest proportion with $84.8 \%$ (565 students), only $15.2 \%$ of students participated in 3 courses.

Table 1

Respondents' demographic

\begin{tabular}{|c|c|c|}
\hline & The number of students & Percentage $(\%)$ \\
\hline \multicolumn{3}{|l|}{ Gender } \\
\hline Male & 280 & 42.0 \\
\hline Female & 386 & 58.0 \\
\hline \multicolumn{3}{|l|}{ Student } \\
\hline Freshman & 199 & 29.9 \\
\hline Sophomore & 174 & 26.1 \\
\hline Junior & 215 & 32.3 \\
\hline Senior & 67 & 10.1 \\
\hline Five-year student & 11 & 1.6 \\
\hline \multicolumn{3}{|l|}{ Working } \\
\hline Full -time & 25 & 3.8 \\
\hline Part- time & 263 & 39.5 \\
\hline Non-working & 378 & 56.7 \\
\hline \multicolumn{3}{|l|}{ Who pay tuition fee } \\
\hline Self-paying & 206 & 30.9 \\
\hline Pay art of tuition fee & 63 & 9.5 \\
\hline Family & 358 & 53.8 \\
\hline Organization & 29 & 4.4 \\
\hline Others & 10 & 1.4 \\
\hline \multicolumn{3}{|l|}{ E-learning hours/week } \\
\hline$<5$ hours/week & 387 & 58.1 \\
\hline 5 to $<=10$ hours/week & 215 & 32.3 \\
\hline 10 to $<=15$ hours/week & 43 & 6.5 \\
\hline$>=15$ hours/week & 21 & 3.1 \\
\hline \multicolumn{3}{|c|}{ The number of online courses } \\
\hline From 0 to 3 & 565 & 84.8 \\
\hline From 4 to 6 & 72 & 10.8 \\
\hline Above 6 & 29 & 4.4 \\
\hline
\end{tabular}

\subsection{Evaluating the reliability of the variable scale}

Based on the criteria mentioned together with the results of the analysis, no observed variables were excluded from the scale. The independent variables "e-learning support service quality", "online instructor quality", "online course material quality", "e-learner's privacy and security", "e-learning service quality" and "e-loyalty" have Cronbach's Alpha coefficients of 0.849 , $0.895,0.864,0.832,0.881$ and 0.841 , respectively are all more than 0.8 , correlation coefficient Particularly, the total variables are in the range from 0.8 to 1 . Thus, the scales of variables all achieve reliability and homogeneity for each concept, with statistical significance and analytical meaning. The scale of the "e-trust" variable has a Cronbach's Alpha coefficient of 0.699 , so according to Nunnally and Bernstein (1967) this scale is acceptable.

\subsubsection{Exploratory factor analysis (EFA)}

After analyzing exploratory factors in the first time, KMO coefficient $=0.956>0.5$ and $\mathrm{Sig}=0.000$ represent a high level of significance. However, the results show that many variables still have load coefficients smaller than 0.5 , so some variables need to be removed. After eliminating unsatisfactory variables (GV1, GV2, GV3, GV4, GV11, STT3, CL8) and some variables were shifted to other factors, the final results are as follows: KMO coefficient $=0.953>0.5$ and Bartlett's test has Sig $=0.000<0.05$ proves that the observed variables are correlated in the overall and suitable for EFA implementation. The number of factors drawn is 7 in accordance with the initial expected number, the observed variables all have factor load factor satisfying conditions greater than 0.5 . The total variance extracted is $54,776 \%>50 \%$ which means that $54,776 \%$ of the variation of factors is caused by observed 
variables.

\subsubsection{Confirmatory factor analysis (CFA)}

The analysis results show that the measurement model was relatively consistent with the survey data, the values ensure the criteria set out $(\mathrm{CMIN}=1593,717 ; \mathrm{df}=640 ; \mathrm{CMIN} / \mathrm{df}=2,490<3 ; \mathrm{P}$-value $=0.000<0.05 ; \mathrm{CFI}=0.921>0.9 ; \mathrm{TLI}=0.913>0.9 ; \mathrm{RMSEA}$ $=0.047<0.08$ ). This result confirms the unidirectional of the scales: e-loyalty, e-trust, e-learning service quality, e-learner's privacy and security, e-learning support service quality, online instructor quality, online course material quality.

Table 2

Result of confirmatory factor analysis (CFA)

\begin{tabular}{|c|c|c|c|c|}
\hline & Variable & Standardized load factor & Reliability Coefficient & AVE \\
\hline \multirow{9}{*}{ E-learning service quality } & CLC6 & .743 & \multirow{9}{*}{0.849} & \multirow{9}{*}{0.413} \\
\hline & CLC5 & .704 & & \\
\hline & CLC4 & .755 & & \\
\hline & CLC3 & .743 & & \\
\hline & STT4 & .188 & & \\
\hline & STT5 & .701 & & \\
\hline & CLC1 & .239 & & \\
\hline & CLC2 & .694 & & \\
\hline & CLC7 & .693 & & \\
\hline \multirow{7}{*}{ E-learning support service quality } & CL4 & .747 & \multirow{7}{*}{0.802} & \multirow{7}{*}{0.429} \\
\hline & CL3 & .608 & & \\
\hline & CL7 & .753 & & \\
\hline & CL5 & .696 & & \\
\hline & CL6 & .686 & & \\
\hline & CL2 & .527 & & \\
\hline & CL1 & .526 & & \\
\hline \multirow{5}{*}{ E-loyalty } & LTT3 & .822 & \multirow{5}{*}{0.845} & \multirow{5}{*}{0.524} \\
\hline & LTT1 & .783 & & \\
\hline & LTT2 & .682 & & \\
\hline & LTT5 & .716 & & \\
\hline & LTT4 & .596 & & \\
\hline \multirow{6}{*}{ Online instructor quality } & GV9 & .752 & \multirow{6}{*}{0.830} & \multirow{6}{*}{0.445} \\
\hline & GV10 & .701 & & \\
\hline & GV7 & .594 & & \\
\hline & GV8 & .681 & & \\
\hline & GV6 & .614 & & \\
\hline & GV5 & .674 & & \\
\hline \multirow{6}{*}{ Online course material quality } & TL3 & .711 & \multirow{6}{*}{0.86} & \multirow{6}{*}{0.507} \\
\hline & TL2 & .688 & & \\
\hline & TL4 & .715 & & \\
\hline & TL6 & .741 & & \\
\hline & TL1 & .666 & & \\
\hline & TL5 & .748 & & \\
\hline \multirow{3}{*}{ E-learner's privacy and security } & BM3 & .817 & \multirow{3}{*}{0.836} & \multirow{3}{*}{0.631} \\
\hline & BM2 & .846 & & \\
\hline & BM1 & .715 & & \\
\hline \multirow{2}{*}{ E-trust } & STT2 & .952 & \multirow{2}{*}{0.769} & \multirow{2}{*}{0.626} \\
\hline & STT1 & .938 & & \\
\hline
\end{tabular}

$\left(C M I N=1593,717 ; d f=640 ; C M I N / d f=2,490 ; P_{-}\right.$value $=0,000 ; C F I=0,921 ;$

The general reliability (CR) of all factor scales $>0.6$ satisfies the established reliability requirement. However, the extracted variance of the scales has reached an approximation to the requirements $(>0.5)$, the scale of variables "e-learning service quality", "e-learning support service quality" and "online instructor quality" with an AVE coefficient of 0.413 , respectively; 0.429 and 0.445 approx. 0.5 . This may be acceptable because the scales are within certain limits of the study time and the new context in Vietnam. The results of confirmatory factor analysis (CFA) show that the general reliability has met the requirement $>0.6$; extracted variance is $>50 \%$, the scales meet the reliability and value requirements for testing the next hypotheses. We adjust the model after analyzing the SEM model.

\subsection{Testing linear structure models (SEM)}

The model presented in this study has 7 variables, including 4 independent variables ("e-learner's privacy and security", "elearning support service quality", "online course material quality", "online instructor quality"); The dependent variable is "eloyalty" and "e-trust". "E-learning service quality" acts as an intermediary variable. Estimated results of standardized, nonstandardized parameters, standard errors, critical values and P-values in the model are presented in detail in Table 5. According to the analysis results in Table 4, we see the index CMIN / $\mathrm{df}=2,531<3$; TLI $=0.91>0.9$; CFI $=0.918>0.9$; P_valuce $=$ $0.000<0.05$; RMSEA $=0.043<0.08$ are consistent with the model according to the assessment of Hu and Bentler (1990) indicating that it is a suitable model with the data being studied. With a significance of $10 \%$ Table 4 shows that "e-learning 
support service quality" has an impact on "e-learning service quality". Specifically, when "e-learning support service quality" increases by 1 unit, "e-quality" increases by 0.073 units. Similar to the independent variable "online course material quality", when "online course material quality" increases by 1 unit, "e-learning service quality" increases by 0.48 units. The results from Table 4 also show that with a 10\% significance level the effect of the "online instructor quality" factor on the factor "elearning service quality" has a corresponding standardized coefficient of 0.071 , the price of the corresponding standard error is 0.057 but the value of $P_{\text {_ value }}=0.214>0.1$ implies that the estimate is not statistically significant, which means that the "online instructor quality" does not affect "e-learning service quality".

Table 3

Evaluating the appropriateness of the research model with the data

\begin{tabular}{llllllll}
\hline & CMIN & df & CMIN/ df & P & TLI & CFI & RMSEA \\
\hline Standard values & $>>$ & $>0$ & $<3$ & $<0.05$ & $>0.9$ & $>0.9$ & $<0.08$ \\
Result & 1637.611 & 647 & 2.531 & 0.000 & 0.910 & 0.918 & 0.043 \\
\hline
\end{tabular}

Therefore, hypothesis 8 is not eligible to accept with $90 \%$ confidence. According to the above research results, the factors "elearner's privacy and security", "e-learning support service quality", "online course material quality" have positive relationship with the factor "overall service quality", the corresponding standardized value is 0.279 respectively; $0.101,0.503$ with $P_{-}$value are less than 0.1. This means that the hypotheses Hypothesis 5, Hypothesis 6, Hypothesis 7 are all accepted with a $10 \%$ significance level. "E-learning support service quality" has an impact on "e-learning service quality". Specifically, when "elearning support service quality" increases by 1 unit, the "e-learning service quality" increases by 0.101 units. Similar to the independent variable "online course material quality", when "online course material quality" increased by 1 unit, the "e-learning service quality" increases by 0.50 units. When the variable "e-learner's privacy and security" increases by 1 unit, the "e-learning service quality" increases by 0.279 units.

Table 4

The impact of the independent variables on the dependent variable

\begin{tabular}{|c|c|c|c|c|c|c|c|}
\hline & \multirow{2}{*}{\multicolumn{2}{|c|}{ Impact }} & \multicolumn{2}{|c|}{ Estimate } & \multirow{2}{*}{$\begin{array}{c}\text { Standardized error } \\
\text { (SE) }\end{array}$} & \multirow{2}{*}{$\begin{array}{l}\text { Critical value } \\
\text { (CR) }\end{array}$} & \multirow{2}{*}{$\mathrm{P}_{\text {value }}$} \\
\hline & & & Unstandardized & Standardized & & & \\
\hline \multirow{4}{*}{ CLC } & $\leftarrow$ & $\mathrm{CL}$ & 0.073 & 0.101 & .038 & 1.937 & .053 \\
\hline & $\leftarrow$ & $\mathrm{BM}$ & 0.203 & 0.279 & .030 & 6.742 & $* * *$ \\
\hline & $\leftarrow$ & $\mathrm{TL}$ & 0.48 & 0.503 & .056 & 8.501 & $* * *$ \\
\hline & $\leftarrow$ & GV & 0.071 & 0.086 & .057 & 1.244 & .214 \\
\hline \multirow{2}{*}{ STT } & $\leftarrow$ & BM & 0.172 & 0.191 & .058 & 2.993 & .003 \\
\hline & $\leftarrow$ & CLC & 0.437 & 0.352 & .082 & 5.312 & $* * *$ \\
\hline \multirow{2}{*}{ LTT } & $\leftarrow$ & CLC & 0.780 & 0.684 & .057 & 13.684 & $* * *$ \\
\hline & $\leftarrow$ & STT & 0.082 & 0.089 & .039 & 2.075 & .038 \\
\hline
\end{tabular}

Also, according to Table 4, the factors "e-learner's privacy and security" and "e-learning service quality" have positive relationships with the factor "e-trust", the value of the standardized coefficients are $0.191,0.335$, respectively and the standard error values are 0.058 and 0.082 , respectively, with $\mathrm{P}_{-}$value are less than 0.1 . This means that the hypotheses $\mathrm{H} 4$, $\mathrm{H} 3$ are accepted with a $10 \%$ significance level. When the "e-learner's privacy and security" of e-learners increases by 1 unit, the etrust increases by 0.191 unit, similarly when the e-learning service quality increases by 1 unit, the e-trust increases by 0.352 unit. The data analysis results also clearly show a positive relationship between "e-trust" and "e-learning service quality" and "e-loyalty" with standardized coefficient values of 0.089 and 0.684 , respectively and standardized deviation of 0.057 and 0.039 , respectively. From that, it can be concluded that Hypothesis 1 and Hypothesis 2 are accepted with a $10 \%$ significance level. We find that when the e-learning service quality increases by 1 unit, e-loyalty increases by 0.684 units and e-trust by 1 unit increases loyalty by 0.089 unit.

Table 5

Hypotheses' testing result

\begin{tabular}{|c|c|c|c|c|}
\hline & Hypothesis & Standardized coefficient & P_value & Result \\
\hline H1 & E-trust has a positive impact on e-loyalty. & 0,089 & $0,0 \overline{3} 8$ & Accepted \\
\hline $\mathrm{H} 2$ & E-learning service quality has a positive impact on e-loyalty. & 0,78 & $<0,001$ & Accepted \\
\hline H3 & E-learning service quality has a positive impact on e-trust. & 0,352 & $<0,001$ & Accepted \\
\hline $\mathrm{H} 4$ & E-learners' privacy and security have a positive impact on e-trust. & 0,191 & 0,003 & Accepted \\
\hline H5 & $\begin{array}{l}\text { E-learner's privacy and security have a positive impact on e-learning service } \\
\text { quality. }\end{array}$ & 0,279 & $<0,001$ & Accepted \\
\hline H6 & $\begin{array}{l}\text { E-learning support service quality has a positive impact on overall e-learn- } \\
\text { ing service quality. }\end{array}$ & 0,101 & 0,053 & Accepted \\
\hline H7 & Online instructor quality has a positive impact on e-learning service quality. & 0,503 & $<0,001$ & Accepted \\
\hline $\mathrm{H} 8$ & Online instructor quality has a positive impact on e-learning service quality. & 0,086 & 0,214 & Rejected \\
\hline
\end{tabular}

The hypotheses are consistent with previous studies except for the impact of online instructor quality on e-learning service quality. Although, Henrie et al. (2018) stated that online instructor quality is mainly based on the quality of teachers and students who want an online course with a strong interaction between teachers and students for better online learning results. But in this study, according to the survey results with a $10 \%$ significance level, it is not possible to prove that "online instructor 
quality" has a positive impact on "e-learning service quality". Explaining what the author group conducted in-depth interviews, the results are mostly explained because the qualifications of online instructors are very good and have deep expertise, so when learners evaluate well or if the service quality is not good enough, they always appreciate lecturers.

\section{Discussion and Conclusion}

The findings confirm that e-learning support service quality, online course material quality and e-learner's privacy and security are fundamental factors, plays an important role for e-learning service quality. The most important factor affecting e-learning service quality is online course material quality, followed by e-learner's privacy and security and e-learning support service quality. This result once again confirms that -service quality was assessed by two groups of factors, namely the group of supportive service quality assessment factors and the translation quality evaluation factor group. Online information technology system service (Shauchenka et al., 2010), a five-factor model was often used to evaluate service quality (SERVQUAL) and improve it to assess the quality of service in online learning. The route that Uppal et al. (2018) research and conclusion that service quality in e-learning is assessed in addition to 5 factors and another factor that has a great influence on whether learning is perfectly reasonable. So as to develop learning materials, the information system program providers need to invest wisely in designing the volume and content of the materials appropriately, in association with practical and social demands, providing skills and knowledge essential for learners, so they can apply to the future. Universities should set up a specialized and responsible Scientific Council for updating the information system and advanced reference content, fulfilling the demands of society, diversity, abundance, serving in students' academic needs. With organizations, businesses can invest in the acquisition, collection and development of updated and necessary resources for them from prestigious universities and experts in the world. From there, it is possible to improve the overall service quality and persuade increasingly more students to participate in courses, benefiting not only for businesses but for the whole society. The results also show that the e-learner's privacy and security and e-learning service quality are the two basic factors that estimate e-trust. This result is consistent with previous studies such as: Bart et al. (2005) point out that security and privacy are a factor influencing the trust of customers in online retail or customers that online payment channels are not always safe and likely to be interrupted (Jones \& Vijayasarathy, 1998), similar to Arnott et al. (2007) defined the security and privacy features of Websites with shared values are important preconditions for trust, research by Ha (2004) and Arnott et al. (2007) point out that a website has a higher level of trust when it protects user privacy. In order for the protection and privacy of online learners to be assured, suppliers need to regularly exchange information about partner banks, network security center, law enforcement departments in advanced technology criminal and state management agencies to promptly respond in case of incidents to ensure the maximum rights of students. Secondly, more attention should be paid to the legal basis of electronic transactions, especially the issue of user protection, the company needs to research and develop a policy to protect the rights of them in the most reasonable and strictest way possible. Ultimately, online organizations must implement safety policies along with strong encryption and authentication processes to be able to stand up to network security and security incidents. In case, if the organization possesses no technical competence, it is necessary to use network security services and regular security solutions to comprehensively protect its website and system. The results of the study confirm that the belief affecting e-loyalty is a correct judgment. This is in addition to previous studies, for example Pham et al. (2018). In addition to trust, e-learning service quality is a strong factor in the loyalty of online learning. Therefore, organizations that offer e-learning programs should realize that in order to build student loyalty, it is necessary to have an advance of online trust and overall quality. The first thing that helps increase trust in the organization is to alleviate students' concerns about personal information management. In addition, online belief is also influenced by the surrounding social environment, the brand and the reputation of the curriculum provider. The research results show that there is a difference in the relationship of online instructor quality and e- service quality in this study with previous studies. Specifically Liaw et al. (2007) stated that "instructors" were a major aspect of online learning. In an online environment, instructors need enough time to interact with students in their learning process (Khan, 2005). The quality of faculty is one of the most important factors determining an effective learning system (Hiltz, 1994; Khan, 2005; Liaw et al., 2007; Selim, 2007; Wang et al., 2007; Webster \& Hackley, 1997). Meanwhile, this study has not been able to confirm the impact of online instructor quality on e-learning service quality.

\section{References}

Akter, S., Ray, P., \& D’Ambra, J. (2013). Continuance of mHealth services at the bottom of the pyramid: the roles of service quality and trust. Electronic Markets, 23(1), 29-47.

Anwar, S., \& Fang, H. (2006). An alternative test of racial prejudice in motor vehicle searches: Theory and evidence. American Economic Review, 96(1), 127-151.

Arnott, D. C., Wilson, D., Mukherjee, A., \& Nath, P. (2007). Role of electronic trust in online retailing. European Journal of Marketing.

Bart, Y., Shankar, V., Sultan, F., \& Urban, G. L. (2005). Are the drivers and role of online trust the same for all web sites and consumers? A large-scale exploratory empirical study. Journal of Marketing, 69(4), 133-152.

Beqiri, M. S., Chase, N. M., \& Bishka, A. (2009). Online course delivery: An empirical investigation of factors affecting student satisfaction. Journal of Education for Business, 85(2), 95-100.

Chiu, C. M., Hsu, M. H., Sun, S. Y., Lin, T. C., \& Sun, P. C. (2005). Usability, quality, value and e-learning continuance decisions. Computers \& Education, 45(4), 399-416.

Cho, V., Cheng, T. E., \& Lai, W. J. (2009). The role of perceived user-interface design in continued usage intention of self-paced e-learning tools. Computers \& Education, 53(2), 216-227.

CIEM (2018). Vietnam's readiness level to participate industrial revolution 4.0: In comparison with that of China. VNEP. 
Corritore, C. L., Kracher, B., \& Wiedenbeck, S. (2003). On-line trust: concepts, evolving themes, a model. International Journal of HumanComputer Studies, 58(6), 737-758.

Cyr, D. (2008). Modeling web site design across cultures: relationships to trust, satisfaction, and e-loyalty. Journal of Management Information Systems, 24(4), 47-72.

Delone, W. H., \& McLean, E. R. (2003). The DeLone and McLean model of information systems success: a ten-year update. Journal of Management Information Systems, 19(4), 9-30.

Doney, P. M., \& Cannon, J. P. (1997). An examination of the nature of trust in buyer-seller relationships. Journal of Marketing, 61(2), 3551.

Eisingerich, A. B., \& Bell, S. J. (2008). Perceived service quality and customer trust: does enhancing customers' service knowledge matter?. Journal of Service Research, 10(3), 256-268.

Elango, R., Gudep, V. K., \& Selvam, M. (2008). Quality of e-Learning: An Analysis Based on e-Learners' Perception of e-Learning. Electronic Journal of E-learning, 6(1), 31-43.

Gambetta, D. (1988 .) CCan We Trust?’, in D. Gambetta (ed.), Trust, Making and Breaking Cooperative Relations (Basil Blackwell, London), pp. 312-237.

Gronroos, C. (1984). A service quality model and its marketing implications.

Ha, H. Y. (2004). Factors influencing consumer perceptions of brand trust online. Journal of product \& brand management.

Shauchenka, H. V., Bleimann, U., Knoll, M., \& Clarke, N. L. (2010). Service Quality Assessment in Distance Learning. In INC (pp. 269277).

Harris, L. C., \& Goode, M. M. (2004). The four levels of loyalty and the pivotal role of trust: a study of online service dynamics. Journal of Retailing, 80(2), 139-158.

Hay, D., Kinchin, I., \& Lygo-Baker, S. (2008). Making learning visible: the role of concept mapping in higher education. Studies in Higher Education, 33(3), 295-311.

Helgesen, Ø., \& Nesset, E. (2007). What accounts for students' loyalty? Some field study evidence. International Journal of Educational Management.

Henrie, C. R., Halverson, L. R., \& Graham, C. R. (2015). Measuring student engagement in technology-mediated learning: A review. Computers \& Education, 90, 36-53.

Henrie, C. R., Bodily, R., Larsen, R., \& Graham, C. R. (2018). Exploring the potential of LMS log data as a proxy measure of student engagement. Journal of Computing in Higher Education, 30(2), 344-362.

Hiltz, S. R. (1994). The virtual classroom: Learning without limits via computer networks. Intellect Books.

Horton, T. R. (2006). The number of nuclei in basidiospores of 63 species of ectomycorrhizal Homobasidiomycetes. Mycologia, 98(2), 233238.

Hu, L. T., \& Bentler, P. M. (1998). Fit indices in covariance structure modeling: Sensitivity to underparameterized model misspecification. Psychological Methods, 3(4), 424.

Hue, H. T., Thuy, N. T., Thom, N. T., \& Giang, T. T. H. (2019). The relationships among overall e-learning service quality, e-learning student trust, and e-learning student loyalty: Evidence in Vietnam. Socio-economic and environmental issues in development, 751.

Jerman-Blažič, B., \& Klobučar, T. (2005). Privacy provision in e-learning standardized systems: status and improvements. Computer Standards \& Interfaces, 27(6), 561-578.

Jones, J. M., \& Vijayasarathy, L. R. (1998). Internet consumer catalog shopping: findings from an exploratory study and directions for future research. Internet Research.

Jun, M., \& Cai, S. (2001). The key determinants of internet banking service quality: a content analysis. International Journal of Bank Marketing.

Urdan, T. A., \& Weggen, C. C. (2004). WRHAMBRECHT+ CO (2000). Corporate E-learning: Exploring A New Frontier.

Kassim, N., \& Abdullah, N. A. (2010). The effect of perceived service quality dimensions on customer satisfaction, trust, and loyalty in ecommerce settings. Asia pacific journal of marketing and logistics.

Kettner-Polley, R. B. (1999). The making of a virtual professor. ALN Magazine, 3(1), 15-23.

Khan, B. H. (Ed.). (2005). Managing e-learning: Design, delivery, implementation, and evaluation. IGI Global.

Kolsaker, A., \& Payne, C. (2002). Engendering trust in e-commerce: a study of gender-based concerns. Marketing intelligence \& planning.

Kotler, P., \& Armstrong, G. (2010). Principles of marketing. Pearson education.

Lau, G. T., \& Lee, S. H. (1999). Consumers' trust in a brand and the link to brand loyalty. Journal of Market-Focused Management, 4(4), $341-370$.

Laurillard, D. (2013). Rethinking university teaching: A conversational framework for the effective use of learning technologies. Routledge.

Lee, B. C., Yoon, J. O., \& Lee, I. (2009). Learners' acceptance of e-learning in South Korea: Theories and results. Computers \& Education, 53(4), 1320-1329.

Lee, Y. C. (2006). An empirical investigation into factors influencing the adoption of an e-learning system. Online information review.

Lee, J. W. (2010). Online support service quality, online learning acceptance, and student satisfaction. The Internet and Higher Education, 13(4), 277-283.

Liaw, S. S., Huang, H. M., \& Chen, G. D. (2007). Surveying instructor and learner attitudes toward e-learning. Computers \& Education, 49(4), 1066-1080.

Liaw, S. S. (2008). Investigating students' perceived satisfaction, behavioral intention, and effectiveness of e-learning: A case study of the Blackboard system. Computers \& Education, 51(2), 864-873.

Liu, C., \& Arnett, K. P. (2000). Exploring the factors associated with Web site success in the context of electronic commerce. Information \& Management, 38(1), 23-33.

Long, M., \& McMellon, C. (2004). Exploring the determinants of retail service quality on the Internet. Journal of Services Marketing.

Luhmann, N. (1979). Trust: A mechanism for the reduction of social complexity. Trust and power: Two works by Niklas Luhmann, 1-103.

Marshall, S. (2006). eMM version two process assessment workbook. Wellington: Victoria University of Wellington.

Masoumi, D., \& Lindström, B. (2012). Quality in e-learning: a framework for promoting and assuring quality in virtual institutions. Journal of Computer Assisted Learning, 28(1), 27-41.

McKnight, D. H., Cummings, L. L., \& Chervany, N. L. (1998). Initial trust formation in new organizational relationships. Academy of Management Review, 23(3), 473-490. 
Moorman, C., Deshpande, R., \& Zaltman, G. (1993). Factors affecting trust in market research relationships. Journal of Marketing, 57(1), 81-101.

Paechter, M., Maier, B., \& Macher, D. (2010). Students' expectations of, and experiences in e-learning: Their relation to learning achievements and course satisfaction. Computers \& Education, 54(1), 222-229.

Parasuraman, A., Zeithaml, V. A., \& Berry, L. L. (1985). A conceptual model of service quality and its implications for future research. Journal of Marketing, 49(4), 41-50.

Parasuraman, A., Zeithaml, V. A., \& Berry, L. L. (1988). Servqual: A multiple-item scale for measuring consumer perc. Journal of Retailing, 64(1), 12

Parasuraman, A., Berry, L., \& Zeithaml, V. (2002). Refinement and reassessment of the SERVQUAL scale. Journal of Retailing, 67(4), 114.

Parasuraman, A., Zeithaml, V. A., \& Malhotra, A. (2005). ES-QUAL: A multiple-item scale for assessing electronic service quality. Journal of Service Research, 7(3), 213-233.

Parasuraman, A., \& Grewal, D. (2000). The impact of technology on the quality-value-loyalty chain: a research agenda. Journal of the Academy of Marketing Science, 28(1), 168-174.

Sun, P. C., Tsai, R. J., Finger, G., Chen, Y. Y., \& Yeh, D. (2008). What drives a successful e-Learning? An empirical investigation of the critical factors influencing learner satisfaction. Computers \& Education, 50(4), 1183-1202.

Pham, L., Williamson, S., \& Berry, R. (2018). Student perceptions of e-learning service quality, e-satisfaction, and e-loyalty. International Journal of Enterprise Information Systems (IJEIS), 14(3), 19-40.

Pham, L., Limbu, Y. B., Bui, T. K., Nguyen, H. T., \& Pham, H. T. (2019). Does e-learning service quality influence e-learning student satisfaction and loyalty? Evidence from Vietnam. International Journal of Educational Technology in Higher Education, $16(1), 7$.

Reichheld, F., \& Schefter, P. (2000). E-loyalty your secret weapon on the Web. Harvard Business Review, July-August, pp.

Ribbink, D., Van Riel, A. C., Liljander, V., \& Streukens, S. (2004). Comfort your online customer: quality, trust and loyalty on the internet. Managing Service Quality: An International Journal.

Rotter, J. B. (1967). A new scale for the measurement of interpersonal trust 1. Journal of Personality, 35(4), 651-665.

Rousseau, D. M., Sitkin, S. B., Burt, R. S., \& Camerer, C. (1998). Not so different after all: A cross-discipline view of trust. Academy of Management Review, 23(3), 393-404.

Schultz, D. E., \& Bailey, S. E. (2000). Customer/brand loyalty in an interactive marketplace. Journal of Advertising Research, 40(3), 4152.

Selim, H. M. (2007). Critical success factors for e-learning acceptance: Confirmatory factor models. Computers \& education, 49(2), 396413.

Sharma, N., \& Patterson, P. G. (1999). The impact of communication effectiveness and service quality on relationship commitment in consumer, professional services. Journal of Services Marketing, 13(2), 151-170.

Shee, D. Y., \& Wang, Y. S. (2008). Multi-criteria evaluation of the web-based e-learning system: A methodology based on learner satisfaction and its applications. Computers \& Education, 50(3), 894-905.

Trentin, G. (1997). Telematics and on-line teacher training: the Polaris Project. Journal of Computer Assisted Learning, 13(4), 261-270.

Udo, G. J. (2001). Privacy and security concerns as major barriers for e-commerce: a survey study. Information Management \& Computer Security.

Uppal, M. A., Ali, S., \& Gulliver, S. R. (2018). Factors determining e-learning service quality. British Journal of Educational Technology, 49(3), 412-426.

VDIC. (2012). Extension phase: Vietnam blended learning program 2011-2015. Journal of Innovative Education, 6(1), $115-133$.

Verhoef, P. C., Franses, P. H., \& Hoekstra, J. C. (2002). The effect of relational constructs on customer referrals and number of services purchased from a multiservice provider: does age of relationship matter?. Journal of the Academy of Marketing Science, 30(3), 202216.

Wang, Y. S., Wang, H. Y., \& Shee, D. Y. (2007). Measuring e-learning systems success in an organizational context: Scale development and validation. Computers in Human Behavior, 23(4), 1792-1808.

Webster, J., \& Hackley, P. (1997). Teaching effectiveness in technology-mediated distance learning. Academy of Management Journal, 40(6), 1282-1309.

Wolfinbarger, M., \& Gilly, M. C. (2003). eTailQ: dimensionalizing, measuring and predicting retail quality. Journal of Retailing, 79(3), 183-198.

Wu, J. H., Tennyson, R. D., \& Hsia, T. L. (2010). A study of student satisfaction in a blended e-learning system environment. Computers \& Education, 55(1), 155-164.

Wu, B. (2016). Identifying the influential factors of knowledge sharing in e-learning 2.0 systems. International Journal of Enterprise Information Systems (IJEIS), 12(1), 85-102.

Yang, Y., \& Cornelious, L. F. (2005). Preparing instructors for quality online instruction. Online Journal of Distance Learning Administration, 8(1), 1-16.

Yoo, B., \& Donthu, N. (2001). Developing a scale to measure the perceived quality of an Internet shopping site (SITEQUAL). Quarterly Journal of Electronic Commerce, 2(1), 31-45.

Zaheer, A., McEvily, B., \& Perrone, V. (1998). Does trust matter? Exploring the effects of interorganizational and interpersonal trust on performance. Organization Science, 9(2), 141-159.

Zeithaml, V. A., Berry, L. L., \& Parasuraman, A. (1996). The behavioral consequences of service quality. Journal of Marketing, 60(2), 3146.

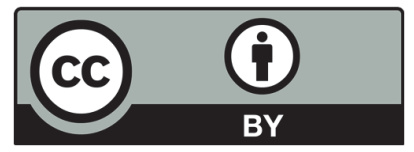

(C) 2020 by the authors; licensee Growing Science, Canada. This is an open access article distributed under the terms and conditions of the Creative Commons Attribution (CC-BY) license (http://creativecommons.org/licenses/by/4.0/). 